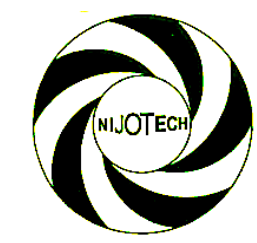

Nigerian Journal of Technology (NIJOTECH)

Vol. 39, No. 2, April 2020, pp. 363 - 368

Copyright@ Faculty of Engineering, University of Nigeria, Nsukka

Print ISSN: 0331-8443, Electronic ISSN: 2467-8821

www.nijotech.com

http://dx.doi.org/10.4314/njt.v39i2.6

\title{
TOWARDS GREEN CONCRETE: RESPONSE OF OYSTER SHELL POWDER-CEMENT CONCRETE TO SPLITTING TENSILE LOAD
}

\author{
O. A. Ubachukwu',* and F. O. Okafor ${ }^{2}$ \\ 1, Dept of Civil Engineering, Michael OKPara Univ. of Agriculture, Umudike, Abia State, Nigeria \\ 2, DePARTMENT OF CiVIL ENGINEERING, UNIVERSITY OF NigeRIA, NSUKKA, ENUGU STATE, NIGERIA \\ E-mail addresses: 1 obiubachukwu@yahoo.com, 2 fidelis.okafor@unn.edu.ng
}

\begin{abstract}
The menacing effects of global warming, rising cost of cement, high energy requirements for the production of cement, and the mitigation of environmental pollution have led researchers towards using locally available materials to partially replace cement in concrete or mortar. The concrete produced from such locally available material is called Green Concrete. Few researches have been reported on the usage of Oyster Shell Powder (OSP) to partially replace the Ordinary Portland Cement (OPC). However, none of those reports has reflected the response of such Green Concrete made with Oyster Shell Powder to Splitting Tensile load. In this research, OPC is partially replaced with OSP at the rate of $0 \%, 5 \%, 10 \%, 15 \%, 20 \%$ and $25 \%$ in concrete. A total of 72 number of cylindrical metal moulds of $150 \mathrm{~mm}$ diameter and $300 \mathrm{~mm}$ height are used to cast the concrete, demoded after 24 hours and cured for 3, 7, 14 and 28 days with three replicates for each curing age and each replacement percentage. The properties of fresh and hardened concrete were quantified. The results show that the increase of OSP from $0 \%$ up to $25 \%$ delays the initial and final setting times of cement paste by $25 \mathrm{mins}$ and $40 \mathrm{mins}$ respectively. It also improves workability by an additional slump of $19 \mathrm{~mm}$. In addition, the Splitting Tensile Strength decreased from $1.706 \mathrm{~N} / \mathrm{mm}^{2}$ for $0 \%$ replacement to $1.011 \mathrm{~N} / \mathrm{mm}^{2}$ for $25 \%$ replacement after a three-day curing period, as well as from 2.076. $\mathrm{N} / \mathrm{mm}^{2}$ for $0 \%$ to $1.388 \mathrm{~N} / \mathrm{mm}^{2}$ for $25 \%$ replacement, after a 28 -day curing period. In as much as the Splitting Tensile Strength of concrete is known to be very low relative to its compressive strength; this study has reflected the extent of vulnerability of OSP-Cement concrete to tensile cracking and stress due to loads. Hence, this will result in safer design and loading of such concrete.
\end{abstract}

Keywords: Concrete, Cement, Oyster Shell Powder, Splitting Tensile Strength, Partial Replacement.

\section{INTRODUCTION}

The construction industry has been described as one of the largest consumers of non-renewable resources [1]. Concrete is the most widely used construction material in the world $[2,3]$. It is the second most consumed substance on earth after water. Cement has no viable recycling potential, each new road; each new building needs new cement [4]. Making cement means making pollution, in the form of carbon dioxide emissions. Cement industry accounts for around 5\% of global emission of carbon dioxide, $\mathrm{CO}_{2}$ which is the main cause of global warming. The environmental concerns stemming from the high energy expense and
$\mathrm{CO}_{2}$ emission associated with cement manufacture have brought about pressures to reduce cement consumption through the usage of Supplementary Cementitious Material (SCM) $[5,6]$. This move is geared towards Green Concrete. Oyster shell powder, whose chemical composition has resemblance with that of limestone powder used in the production of cement has been used effectively to partially replace cement in concrete without compromise to the concrete properties, while offering the advantages of environmental management, pollution, and cost reduction [7-11]. Oyster is seafood, protected by hard bivalve shells. Usually, the fleshes are processed for

* Corresponding author, tel: +234 8035014452 
consumption, while the inedible hard shells are dumped at open sites, thereby causing environmental pollution. In Nigeria, oyster shells are found in the Niger Delta region located at latitude $5.3261^{\circ} \mathrm{N}$ and longitude $6.4708^{\circ} \mathrm{E}$. Niger Delta is the delta of the Niger River at the Gulf of Guinea on the Atlantic Ocean in Nigeria. The region has a tropical climate with two distinct wet and dry seasons. The mean annual rainfall usually exceeds $3500 \mathrm{~mm}$ along the coast. It has annual mean temperature of between $18^{\circ} \mathrm{C}$ to $35^{\circ} \mathrm{C}$ [12]. These make the Niger Delta region a good habitat for oysters; hence, enough waste shells. This study is focused on changing 'waste' into wealth by recycling Oyster Shell Powder (OSP) from oyster shells for partial replacement of cement for Green Concrete, with particular emphasis on the Splitting Tensile Strength of the concrete produced. According to Otuonye and Odebiyi [13], the Splitting Tensile Strength is a measure of the ability of material to resist a force that tends to pull it apart. It is expressed as the minimum tensile stress needed to split the material apart. This type of test is not routinely performed; hence, limited existing literature [5]. Consequently, this study will bridge the gap of near absence of literature on the subject.

\section{MATERIALS AND METHOD}

\subsection{Materials}

Dangote brand of Ordinary Portland cement, bought from Building Materials Market, Umuahia, Abia State, Nigeria was used in this research. The Ordinary Portland Cement conformed to the requirements of [14]. The river sand was sourced from Imo River in Imo State, Nigeria. It was sieved through $10 \mathrm{~mm}$ B.S test sieve to remove cobbles. The sand was sharp and free from deleterious substances and conforms to the requirements of [15]. The granite was sourced from the quarry site at Ishiagu, Ebonyi State, Nigeria. The maximum size of aggregate used for this work was $20 \mathrm{~mm}$ diameter. It was thoroughly flushed with water to reduce the level of impurities and organic matter; to conform to requirements [16]. The water used for the study was obtained from borehole at College of Engineering and Engineering Technology, Michael Okpara University of Agriculture, Umudike, Abia State. The water was clean and free from any visible impurities. It conformed to the requirements of [17]. The water did not contain harmful constituents in such quantities as may be detrimental to the setting, hardening and durability of the concrete. Oyster shells used for this research were collected from the bank of Okwagwe River at Ogodobiri Community, Bomadi Local Government Area, Delta State, Nigeria, where they were discarded by fishermen, after taking the fleshy part of the oyster as food/meat.

\subsection{Method}

The oyster shells were soaked in water for approximately 48 hours, before washing them thoroughly, so as to completely remove the remaining flesh attached to the shells. The shells were then spread under the sun, for drying. Fig. 1 shows a sample of oyster shells being sun-dried, after washing. The washed and sun-dried oyster shells were mechanically crushed with the aid of Hammer Mill Machine of brand TRF400, with Motor $2.0 \mathrm{CV}-50 \mathrm{~Hz}$ 2poles, Voltage 220v-Monophase, where they were passed through several screens so as to obtain fine particles, passing through $150 \mu \mathrm{m}$ sieve. The pulverization process is shown in Fig. 2.

The physical properties of the materials: sand, granite, cement, oyster shell powder were obtained and ensured that they conformed to the set standards. The mix design was done for concrete slump, $75-100 \mathrm{~mm}$ and water/cement ratio of 0.5 and maximum size of aggregate as $20 \mathrm{~mm}$. The specific gravity of sand, granite, cement and OSP are 2.6, 2.74, 3.15 and 2.63 respectively. The mix design came up with this mix ratio of 1:1.6:2.8 for binder, sand, and granite respectively. Dry mix method was used for concrete constituent before the addition of water. The homogenized mixture was then introduced into cylindrical metal mould of diameter, $150 \mathrm{~mm}$ and height, $300 \mathrm{~mm}$, in layers of $50 \mathrm{~mm}$ and compacted with the tamping rod, 25 strokes per layer and the top finish with the trowel and label accurately conforming to [18]. The concrete was de-moulded after 24 hours and immersed in a curing tank, while the splitting tensile strength test was performed after $3,7,14$, and 28 days. A total of 72 cylinders of concrete were cast. The chemical composition of OSP was also investigated, as well as the setting times of cement paste, workability of concrete using the slump cone. Each sample was replicated thrice for each curing period and for each dosage level of $0 \%, 5 \%, 10 \%$, $15 \%, 20 \%$, and $25 \%$. 


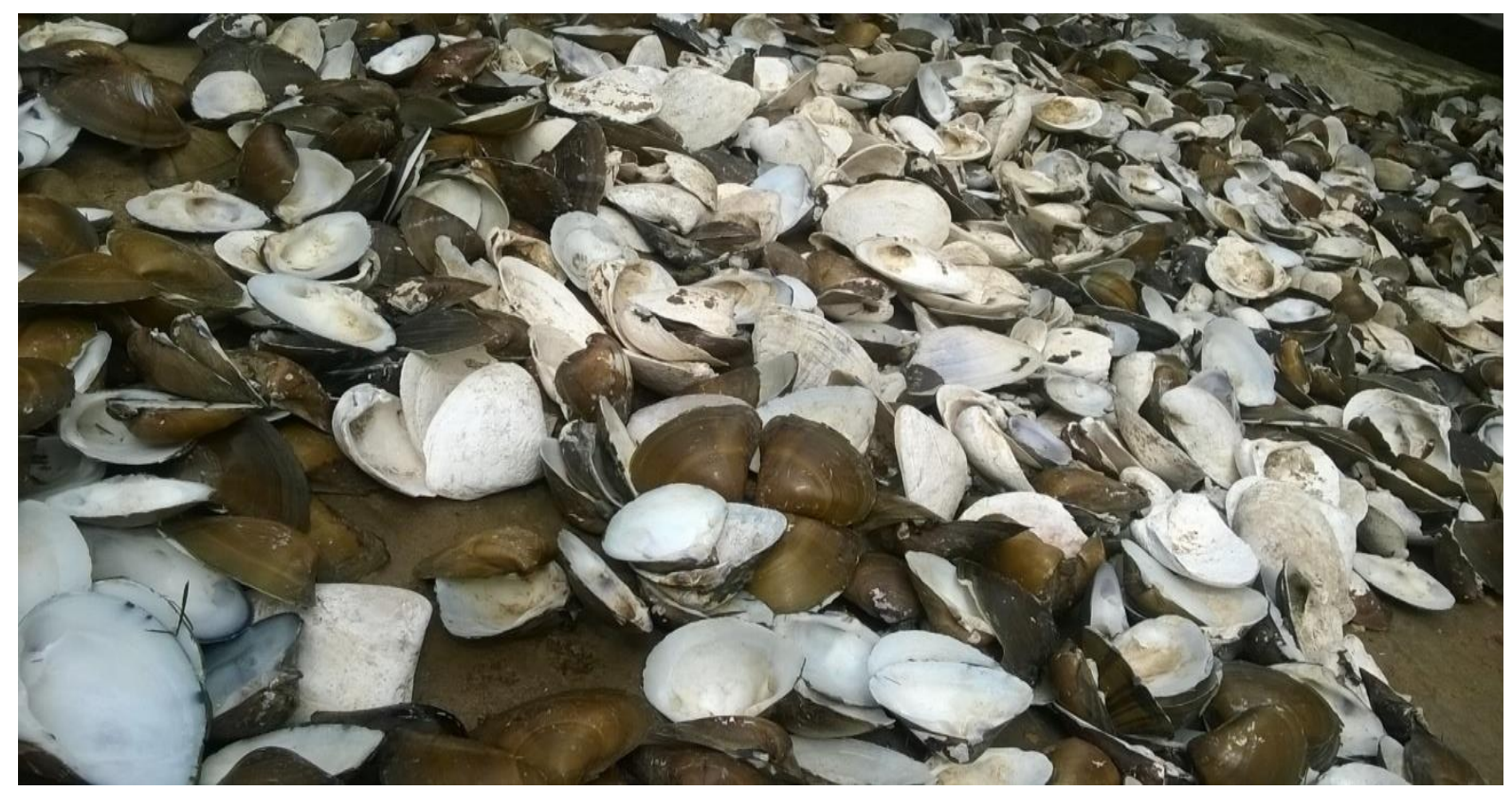

Fig. 1: Washed Oyster Shells Being Sun-dried After Washing

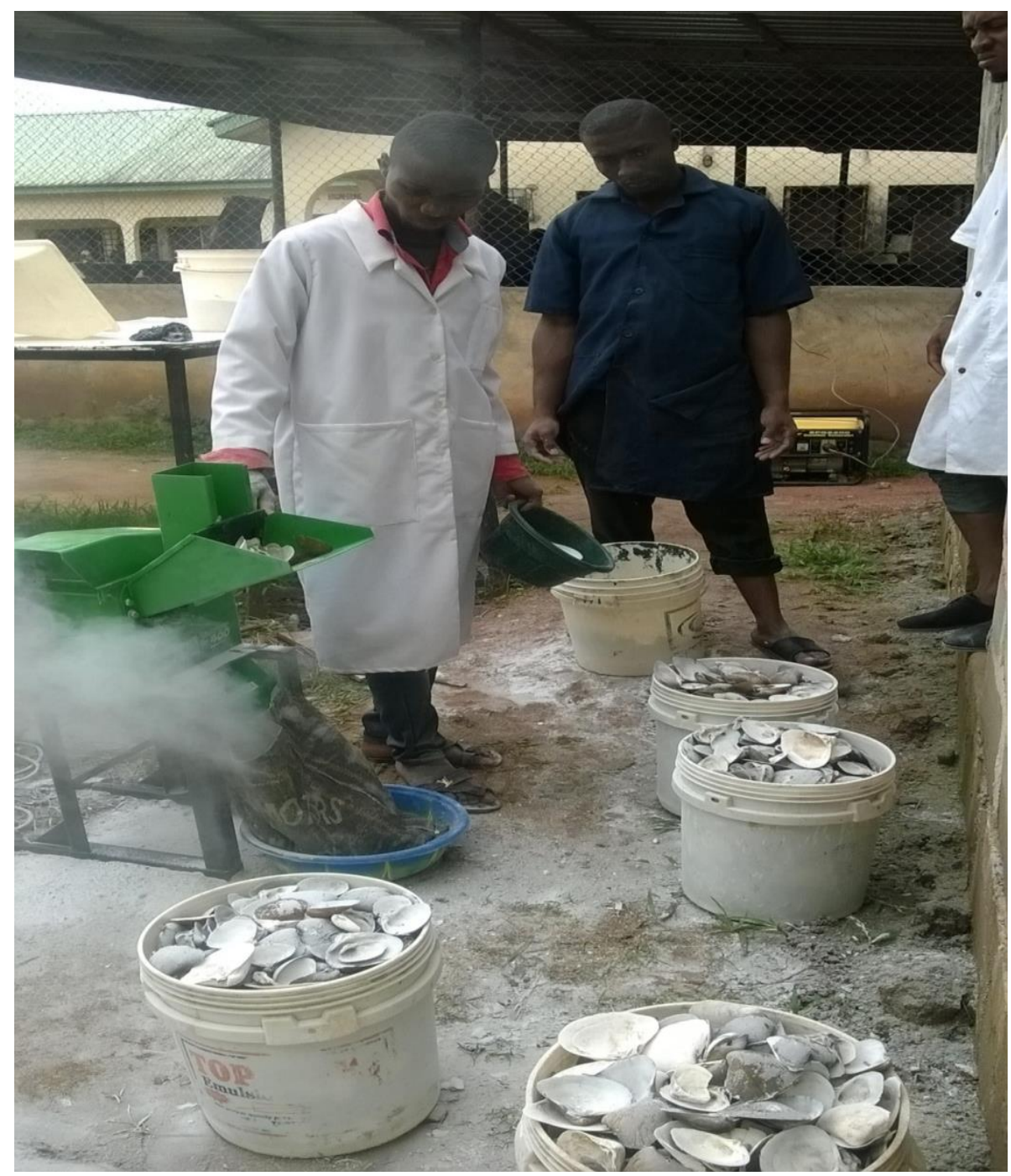

Fig 2: Oyster Shells undergoing Crushing by Hammer Mill Machine 


\section{RESULTS AND DISCUSSIONS}

\subsection{Chemical Analysis of Oyster Shell Powder}

X-Ray Fluorescence (XRF) Spectroscopic analysis was performed on the sample so as to obtain the main components of OSP shown in Table 1

Loss on Ignition (LoI) for OSP was obtained as $40.50 \%$. The weight loss due to ignition is high because, calcium carbonate, $\mathrm{CaCO}_{3}$ undergoes decomposition into calcium oxide, $\mathrm{CaO}$ and carbon dioxide, $\mathrm{CO}_{2}$ at temperature above $850^{\circ} \mathrm{C}$. This is in harmony with the work of [8]. According to [19], we cannot obtain directly the weight of $\mathrm{CaCO}_{3}$ from Table 1 .

Weight of $\mathrm{CaCO}_{3}=\left(\mathrm{CaCO}_{3}\right.$ molecular weight $/ \mathrm{CaO}$ molecular weight) $\times \mathrm{CaO}$ weight ratio in $\%$

$$
=(100 / 56) \times 54.55=97.41 \%
$$

The quantity of $\mathrm{CaO}$ in OSP is sufficient to form silicates and aluminates of calcium. The composition of oyster shell powder is similar to that of limestone powder used in the production of cement as shown in Table 1; hence, can partially replace cement.

\subsection{Variation of Initial and Final Setting Times}

The setting times of cement/oyster shell powder, both initial and final are reported in Table 2.

Table 2 shows that, as the quantity of OSP increases, both the initial and final setting times get increased also, compared to those of grade 43 Ordinary Portland Cement. This is due to reduction in the strengthforming compounds, $\mathrm{C}_{3} \mathrm{~S}, \mathrm{C}_{2} \mathrm{~S}$, and $\mathrm{C}_{3} \mathrm{~A}$ in the cement paste. This increased setting times become advantageous while concreting in hot weather.

\subsection{Workability of Fresh Concrete}

Table 3 shows the results of the workability test, using the slump cone. All the slump values are true slumps and are within the design range of $75-100 \mathrm{~mm}$ in the mix design.

It is observed that the workability of freshly prepared OSP-cement concrete is better than that of OPC concrete. As the replacement level of OSP increases from $5 \%$ to $25 \%$ ( $80 \mathrm{~mm}$ to $99 \mathrm{~mm}$ respectively), the workability increased by extra $19 \mathrm{~mm}$. Since the increase in OSP leads to increase in workability, the net result is lower bleeding and segregation in concrete. An improved workability also offers advantage of easier placing and compaction of OSP-concrete as against the OPC concrete, since workability is maintained at a longer time. Hence, it will lead to increased durability of OSP-cement concrete.

\subsection{Splitting Tensile Strength}

For want of space, the results of the splitting tensile strength of each percentage replacement level with each curing period were not shown in three replicates. Hence, the average splitting tensile strengths after curing the concrete cubes for 3, 714 and 28 days are given in Figure 3.

Table 1: Chemical Composition of Principal Materials in OPC and OS $P$

\begin{tabular}{lllllllllll}
\hline Oxide & $\mathrm{SiO}_{2}$ & $\mathrm{Al}_{2} \mathrm{O}_{3}$ & $\mathrm{Fe}_{2} \mathrm{O}_{3}$ & $\mathrm{CaO}$ & $\mathrm{MgO}$ & $\mathrm{K}_{2} \mathrm{O}$ & $\mathrm{Na}_{2} \mathrm{O}$ & $\mathrm{TiO}_{2}$ & $\mathrm{P}_{2} \mathrm{O}_{5}$ & $\mathrm{SO}_{3}$ \\
\hline OPC & 19.07 & 3.65 & 2.35 & 63 & 2.51 & 0.97 & 0.14 & 0.28 & 0.17 & 8.52 \\
OSP & 2.10 & 0.59 & 0.16 & 54.55 & 0.58 & 0.03 & 0.73 & 0.06 & 0.19 & 0.52 \\
\hline
\end{tabular}

*LoI includes $\mathrm{CO}_{2}$ and organic materials lost due to heating

Table 2: Variation of Initial and Final Setting Times with Cement Partial Replacement

\begin{tabular}{ccc}
\hline $\begin{array}{c}\text { OSP } \\
\text { Percentage } \\
\text { Replacement }\end{array}$ & $\begin{array}{c}\text { Initial Setting } \\
\text { Time (mins) }\end{array}$ & $\begin{array}{c}\text { Final Setting } \\
\text { Time (mins) }\end{array}$ \\
\hline $0 \%$ & 45 & 105 \\
$5 \%$ & 50 & 120 \\
$10 \%$ & 55 & 135 \\
$15 \%$ & 60 & 140 \\
$20 \%$ & 65 & 150 \\
$25 \%$ & 70 & 155 \\
\hline
\end{tabular}

Table 3: Variation of S/ump of OSP-Cement

\begin{tabular}{|c|c|c|}
\hline \multicolumn{3}{|c|}{ Concrete } \\
\hline OSP & Height of & Slump of \\
\hline $\begin{array}{l}\text { Percentage } \\
\text { Replacement }\end{array}$ & $\begin{array}{l}\text { Concrete } \\
(\mathrm{mm})\end{array}$ & $\begin{array}{c}\text { Concrete } \\
(\mathrm{mm})\end{array}$ \\
\hline $0 \%$ & 220 & 80 \\
\hline $5 \%$ & 218 & 82 \\
\hline $10 \%$ & 214 & 86 \\
\hline $15 \%$ & 211 & 89 \\
\hline $20 \%$ & 205 & 95 \\
\hline $25 \%$ & 201 & 99 \\
\hline
\end{tabular}




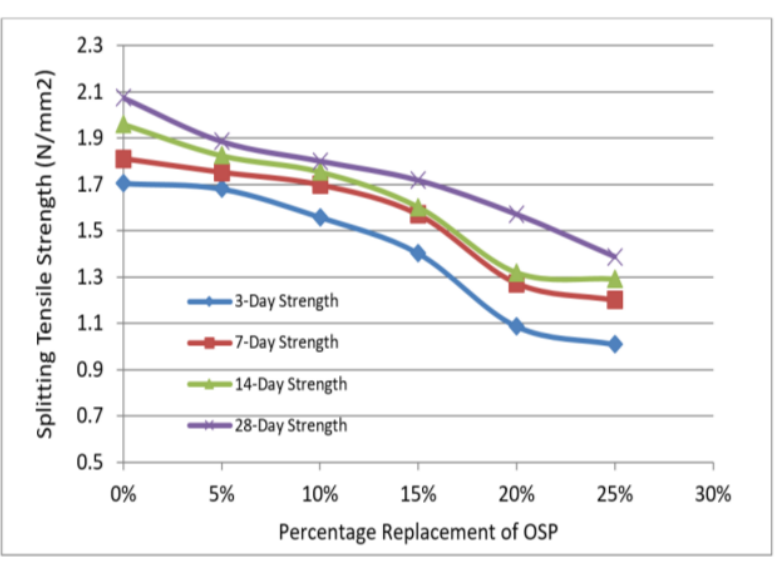

Fig. 3: Variation of Splitting Tensile Strength with Curing Age as Percentage Replacement of OSP Varies

It is generally observed that as the percentage replacement of cement with OSP continues to increase, the average splitting tensile strengths continue to decrease. For instance, the average splitting tensile strength of the concrete decreased from $1.706 \mathrm{~N} / \mathrm{mm}^{2}$ for $0 \%$ replacement to $1.011 \mathrm{~N} / \mathrm{mm}^{2}$ for $25 \%$ replacement after a three-day curing period, as well as from $2.076 . \mathrm{N} / \mathrm{mm}^{2}$ for $0 \%$ to $1.388 \mathrm{~N} / \mathrm{mm}^{2}$ for $25 \%$ replacement, after a 28 -day curing period. This decrease is as a result of less reactive material of OSP mixed with Portland cement, leading to higher water demand; thus, reduced splitting tensile strength. On the other hand, the average splitting tensile strength of OSP concrete continues to increase from curing age of 3 days to 28 days for all the percentage replacements. This is expected as hydration of cement leads to gain in strength, be it compressive, flexural or splitting tensile strengths.

\section{CONCLUSION}

The present study was geared towards investigating the response of OSP-cement concrete to Splitting Tensile loads as Green concrete for healthier environment. The rheological and hardened properties of concrete produced using the readily available OSP as partial replacement of cement were also studied. From the foregoing results and discussions, the following conclusions are hereby drawn:

(i) As the percentage replacement of cement with OSP increases, both the Initial and Final setting times of cement paste increase.

(ii) As the percentage replacement of cement with OSP increases, the workability of the fresh concrete improves; hence, better compaction which will enhance the durability of concrete.

(iii) Increase in the replacement of OSP results in gradual decrease in the Splitting Tensile Strength of concrete at all ages ( 3 , 7, 14 and 28 days). The Splitting Tensile Strength of concrete has been found to be small relative to its Compressive Strength.

(iv) OSP mainly comprises $\mathrm{CaCO}_{3}$ with other oxides in trace amounts. The similarity with the chemical composition of OPC gives it the ability to partially replace Ordinary Portland Cement in concrete and mortars.

Finally, the results of the investigation have provided a firm foundation for further research into the performance of Green Concrete made with OSP as partial replacement of cement, with particular emphasis on its Splitting Tensile Strength.

\section{REFERENCES}

[1] Wallbaum, H.; Buerkin, C., "Concept and Instrument for a Sustainable Construction Sector" Industry and Environment, 26: pp53-57, 2003

[2] Aitcin, P. C., "Cements of Yesterday and Today, Concrete of Tomorrow", Cement and Concrete Research, Vol. 30 (13), pp1349-1359, 2000

[3] Mobasher, B., "USA-Concrete Construction Industry: Cement Based Materials and Civil Infrastructures" Proceedings of CBM-CI International Workshop, Karachi, Pakistan, pp7390, 2008

[4]

http://www.nytimes.com/2007/10/26/business/ nor/dbusiness/26cement Accessed on January 13,2014

[5] Mindess, S., Young, F.J. and Darwin, D., "Concrete", 2nd Edition, Upper Saddle River: Prentice Hall, 2003

[6] Sabir, B.B., Wild, S. and Bai, J., "Metakaolin and Calcined Clays as Pozzolans for Concrete: A Review", Journal of Cement and Concrete Composites, 23(6): pp441-454, 2001

[7] Etuk, B. R.; Etuk, I. F. and Asuquo, L. O., "The Feasibility of Using Seashell Ash Admixtures for Concrete". Journal of Environmental Sciences and Engineering, A1: pp121-127, 2012

[8] Lerwattanaruk, P.; Natt, M.; and Chalothorn, S., "Utilization of Ground Waste Seashells in Cement Mortars for Masonry and Plastering", Journal of 
Environmental Sciences and Management III: pp133-141, 2012

[9] Chou-Fu Liang and Hung-Yu Wang, "Feasibility of Pulverized Oyster Shell as a Cementing Material", Advances in Materials Sciences and Engineering, Hindawi Publishing Corporation, pp17, 2013

[10] Wen-Ten Kuo, Her-Yung Wang, Chun-Ya Shu, De-Sin Su, "Engineering Properties of Controlled Low-strength Material Containing Waste Oyster Shells," Journal of Construction and Building Materials. 46: pp128-133, 2013

[11] Zhong, Bin-Yang, Zho; Qiang, Chan; Chan, Chang-Feng; Yu, Yan (2012), "Structure and Property Characterization of Oyster Shell Cementing Material", Chinese Journal of Struct. Chem., Vol. 31 (1), pp85-92

[12] Alayaki, F. M.; Al-Tabbaa, A.; and Ayotamuno, M. J., "Stabilization of Niger Delta Fat Clay with Blend of Binders for Subgrade Application - Part 1", Nigerian Journal of Technology, Vol. 36, No. 3, pp740-748, 2017

[13] Otuonye, A. W.; and Odebiyi, A. J., "Regression Modelling of Strength Properties of Concrete
Reinforce with Polypropylene Fibre and Alkali Resistant Glass Fibre", Nigerian Journal of Technology, Vol. 37 (4), pp898-906, 2018

[14] BS12, "Specification for Portland Cement", British Standards Institution, London, 1996

[15] BS812 Part 1, "Method of Determination of Particle Size and Shape", British Standards Institution, London, 1975

[16] BS882, "Specification for Aggregates from Natural Sources for Concrete", British Standards Institution, London, 1992

[17] BS 3140, "Methods of Test for Water for Making Concrete, Including Notes on the Suitability of the Water", British Standards Institution, London, 1980

[18] BS206, "Concrete-Performance, Production, Placing and Compliance Criteria", British Standards Institution, London, 1992

[19] Zhong Bin-Yang, Zhou Qiang, Chan ChangFeng, Yu Yan, "Structure and Property Characterization of Oyster Shell Cementing Material", Chinese Journal of Structures Chem. Vol. 31, 1, pp85 -92, 2012 